\title{
ASPECTS OF THE REPRODUCTIVE ECOLOGY OF FEMALE TURTLES IN NEW MEXICO
}

\author{
Jeffrey E. Lovich ${ }^{1}$, Mickey Agha ${ }^{2}$, Charles W. Painter ${ }^{3}$, Levi Cole ${ }^{4}$, \\ Austin Fitzgerald ${ }^{5}$, Kevin Narum ${ }^{6}$, and Randy D. Jennings ${ }^{7}$
}

\begin{abstract}
Data on reproductive ecology of turtles in New Mexico are limited, and some species living there are among the least studied in the United States. We trapped 4 native species of turtles (Apalone spinifera, Chrysemys picta, Pseudemys gorzugi, and Trachemys gaigeae gaigeae) in the Rio Grande and Black River (Pecos River drainage) of New Mexico in June 2012 and 2013 to collect data on female reproductive ecology, including clutch size, egg size, timing of egg production, and percentage of gravid females. During our sampling, we found shelled eggs via X-radiography in only 3 native species: C. picta, P. gorzugi, and T. g. gaigeae. Clutch and egg sizes were within the range of previously reported values, although clutch size for P. gorzugi $(10 \mathrm{eggs})$ is only the second published record for that data-deficient species. Clutch size increased with body size in T. g. gaigeae. We observed few differences between reproductive parameters for turtles in New Mexico and their conspecifics and congeners elsewhere in the United States, other than the observation that female C. picta may mature at smaller body sizes in New Mexico relative to other western populations elsewhere in its vast, primarily eastern North American range.
\end{abstract}

REsumen.-Los datos sobre la ecología reproductiva de las tortugas en Nuevo México son limitados y algunas de las especies que viven allí están entre las menos estudiadas en los Estados Unidos. Capturamos cuatro especies de tortugas nativas (Apalone spinifera, Chrysemys picta, Pseudemys gorzugi, y Trachemys gaigeae gaigeae) en el Río Grande y Black River (drenaje del Río Pecos) de Nuevo México, en junio del 2012 y 2013, con el fin de recopilar datos sobre la ecología reproductiva femenina, incluyendo el tamaño de la puesta, el tamaño de los huevos, el momento de la producción de los huevos y el porcentaje de hembras grávidas. Durante nuestro muestreo, encontramos huevos con rayos X en sólo tres especies nativas: C. picta, P. gorzugi, y T. g. gaigeae. El tamaño de puesta y de los huevos se situó dentro del rango de valores previamente reportados, sin embargo el tamaño de la puesta de $P$. gorzugi (10 huevos) es tan sólo el segundo registro publicado sobre esta especie. El tamaño de la puesta aumenta con el tamaño del cuerpo de T. g. gaigeae. Además del hecho de que las hembras de C. picta podrían madurar a tamaños corporales relativamente más pequeños en Nuevo México, en relación con otras poblaciones del oesta, principalmente en el área del este de América del Norte, hemos observado algunas diferencias entre los parámetros reproductivos de las tortugas en Nuevo México, y entre sus conespecíficos y congéneres en otros lugares de los Estados Unidos.

Research on turtles in the southwestern United States lags far behind that in the Southeast where turtle diversity is substantially higher (Buhlmann et al. 2009). Several southwestern turtle species (Lovich and Beaman 2008) rank among the most poorly studied species in the United States (Lovich and Ennen 2013), although information on one, Trachemys gaigeae gaigeae, is steadily increasing (Ernst 1992, Stuart and Ernst 2004, Stuart and Ward 2009). Recent reviews of the ecology of turtles in the United States (Ernst and Lovich 2009) and all reptiles and amphibians in New Mexico (Degenhardt et al. 1996) demonstrate that little has been published on the ecology of turtles in New Mexico, with a few notable exceptions (e.g., Christiansen and Dunham 1972, Stuart 1995, Morjan and Stuart 2001). Even basic information on the distribution and native status (sensu Webb 1985) of southwestern turtles is still accumulating (Lovich et al. 2014). Although New Mexico is an arid state, it has a comparatively high diversity of native turtles, with 10 species currently recognized, 9 of which occupy aquatic environments for substantial portions of the year (Degenhardt et al. 1996).

Many turtles in New Mexico have wide distributions in the United States and Canada, with only small portions of their ranges

\footnotetext{
${ }^{1}$ U.S. Geological Survey, Southwest Biological Science Center, 2255 North Gemini Drive, MS-9394, Flagstaff, AZ 86001-1600. E-mail: jeffrey_lovich@usgs.gov ${ }^{2}$ Department of Wildlife, Fish, and Conservation Biology, University of California, Davis, One Shields Avenue, Davis, CA 95616.

${ }^{7}$ Western New Mexico University, Department of Natural Sciences, Box 680, Silver City, NM 88062.
} 
extending into New Mexico. This contributes to the dearth of state-specific ecological and reproductive data for most turtle species that are otherwise fairly well studied outside New Mexico. For example, due to their wide distributions, some turtles such as Chrysemys picta are among the best studied (Lovich and Ennen 2013) based on research in other parts of the United States and Canada. Others, like T. g. gaigeae and Pseudemys gorzugi, continue to be poorly studied (Lovich and Ennen 2013) and have only limited information specifically from New Mexico. Ongoing population surveys of turtles in and around Elephant Butte Reservoir (EBR) on the Rio Grande and the Black River of New Mexico provided an opportunity to collect additional data on female reproductive ecology for several turtle species that we summarize in this paper.

\section{METHODS}

Several of the authors have monitored turtle populations in the Rio Grande and Pecos River in New Mexico for several decades. Turtle research in New Mexico began in the 1970s (Degenhardt and Christiansen 1974, Degenhardt et al. 1996) and intensified in the 1990s at EBR on the Rio Grande (Sierra Co.) near Truth or Consequences (Stuart and Painter 2002). Because of the paucity of information on reproductive ecology of female turtles in New Mexico, we trapped turtles during 2012 and 2013 (Lovich 2016) with hoop traps baited with canned sardines (Gibbons 1988) to collect data on clutch size, egg size, and percentage of gravid females. From 13 June to 15 June 2012, we trapped T. g. gaigeae and C. picta at EBR and in ponds below the dam and oxbows along the lower lake. We trapped P. gorzugi on the Black River, a tributary of the Pecos River in Eddy County, on 13 June. A replicate trapping effort was conducted at EBR from 19 June to 20 June 2013. The nesting season at EBR starts as early as 31 May for T. g. gaigeae (Morjan and Stuart 2001). Due to protracted drought, lake levels were extremely low during both sampling efforts (Woodhouse et al. 2013, Cook et al. 2015).

Turtle sex was determined based on differences in pre-cloacal tail length between males and females (Ernst and Lovich 2009), and straight-line carapace lengths (SLCL) were measured with tree calipers to the nearest
$1 \mathrm{~mm}$. Female turtles were $\mathrm{X}$-rayed in the field with a portable digital X-ray system (Canon ${ }^{\circledR}$ and MinXray ${ }^{\circledR}$ TR-80 components) to determine clutch presence, clutch size, and egg width. X-radiographs were generated at $60 \mathrm{kV}$ with an exposure of $0.1 \mathrm{~s}$, settings that are considered safe for the females and embryos (Hinton et al. 1997). We X-rayed most females above or near the previously published minimum sizes at maturity for each species (Ernst and Lovich 2009, Legler and Vogt 2013). The exceptions included $P$. gorzugi and T. g. gaigeae, since timing of maturity is not well defined in either species and may vary latitudinally in the latter species (Stuart and Ward 2009). Females of T. g. gaigeae are assumed to mature at a carapace length of 160 $\mathrm{mm}$ (Legler and Vogt 2013) to $169 \mathrm{~mm}$ (Legler 1960). Our sample included 3 females between $135 \mathrm{~mm}$ and $160 \mathrm{~mm}$ SLCL that were $\mathrm{X}$-rayed to test the lower estimate. Greatest egg widths $(\mathrm{EW})$ were measured directly from digital images of X-radiographs to the nearest $0.01 \mathrm{~mm}$ using K-PACS software (version 1.5.0) after calibrating measurements with a penny placed on the X-ray detector plate during each exposure. Statistical analyses were conducted using SYSTAT (version 13.1) and Program R (version 3.2.3; R Core Team 2013). Turtles were released at the point of capture except for Trachemys scripta individuals. That taxon was removed from the Rio Grande basin by the New Mexico Department of Game and Fish because it is an invasive species.

\section{RESULTS}

During 2012, three female C. picta with SLCLs of 144,148 , and $149 \mathrm{~mm}$ were collected in an oxbow pond near EBR, and 2 were gravid. The smallest female $(144 \mathrm{~mm})$ contained 7 shelled eggs and the $148 \mathrm{~mm}$ female contained 8 shelled eggs (Table 1). Neither clutch was heavily shelled as would be expected if oviposition was imminent. EW ranged from 16.7 to $18.2 \mathrm{~mm}(\bar{x}=17.4$, SD 0.3 ). Mean EW was not statistically different between the 2 females (Student's $t$ test, pooled variance: $t=-0.11, \mathrm{df}=13, P=0.91$ ).

Six female $P$. gorzugi ranging from 210 to $266 \mathrm{~mm}$ SLCL were collected on the Black River. Only one (242 mm SLCL) was gravid (17\%), and she contained 10 shelled eggs with EWs from 27.2 to $30.5 \mathrm{~mm}(\bar{x}=29.3$, SD 1.1). 


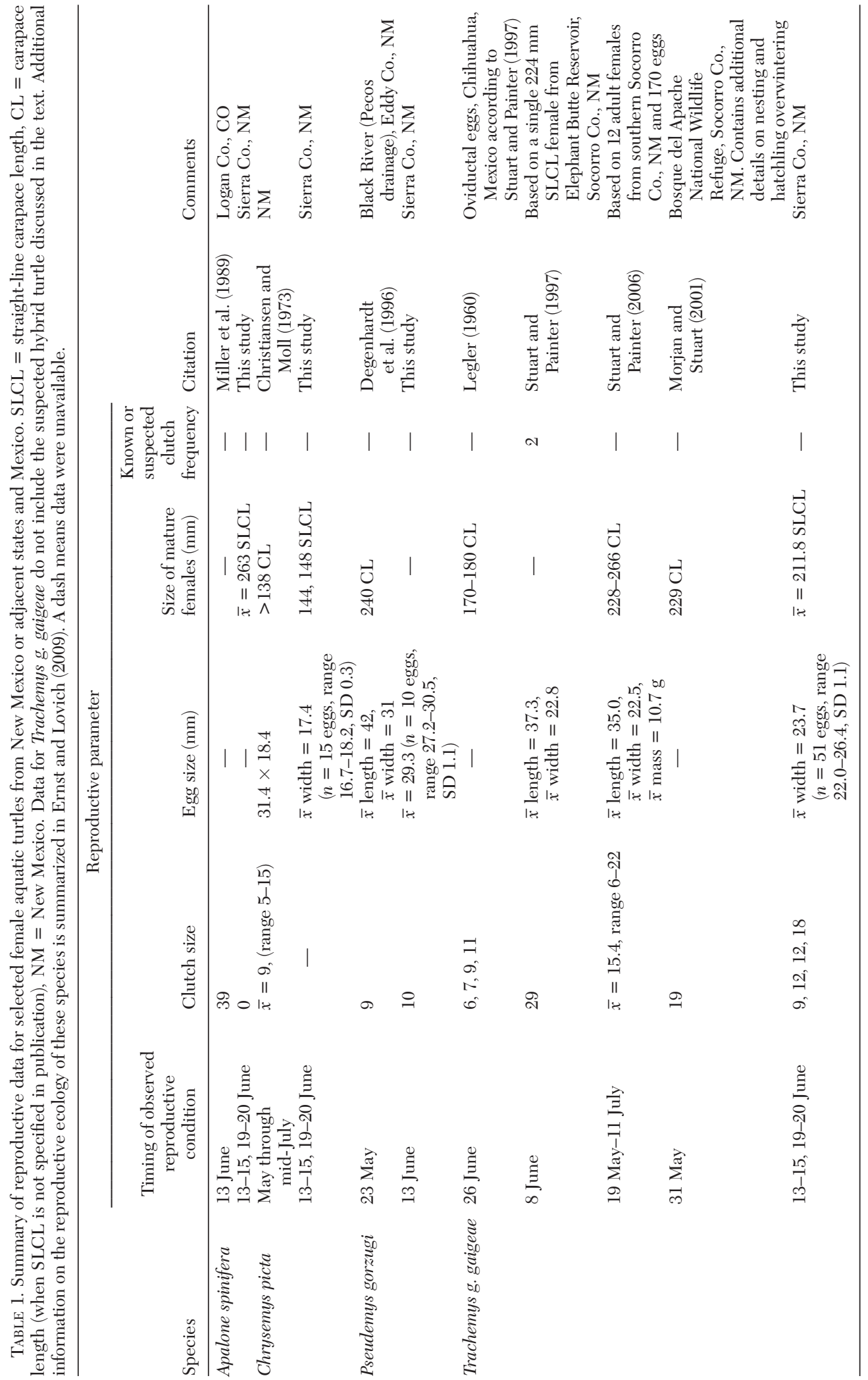




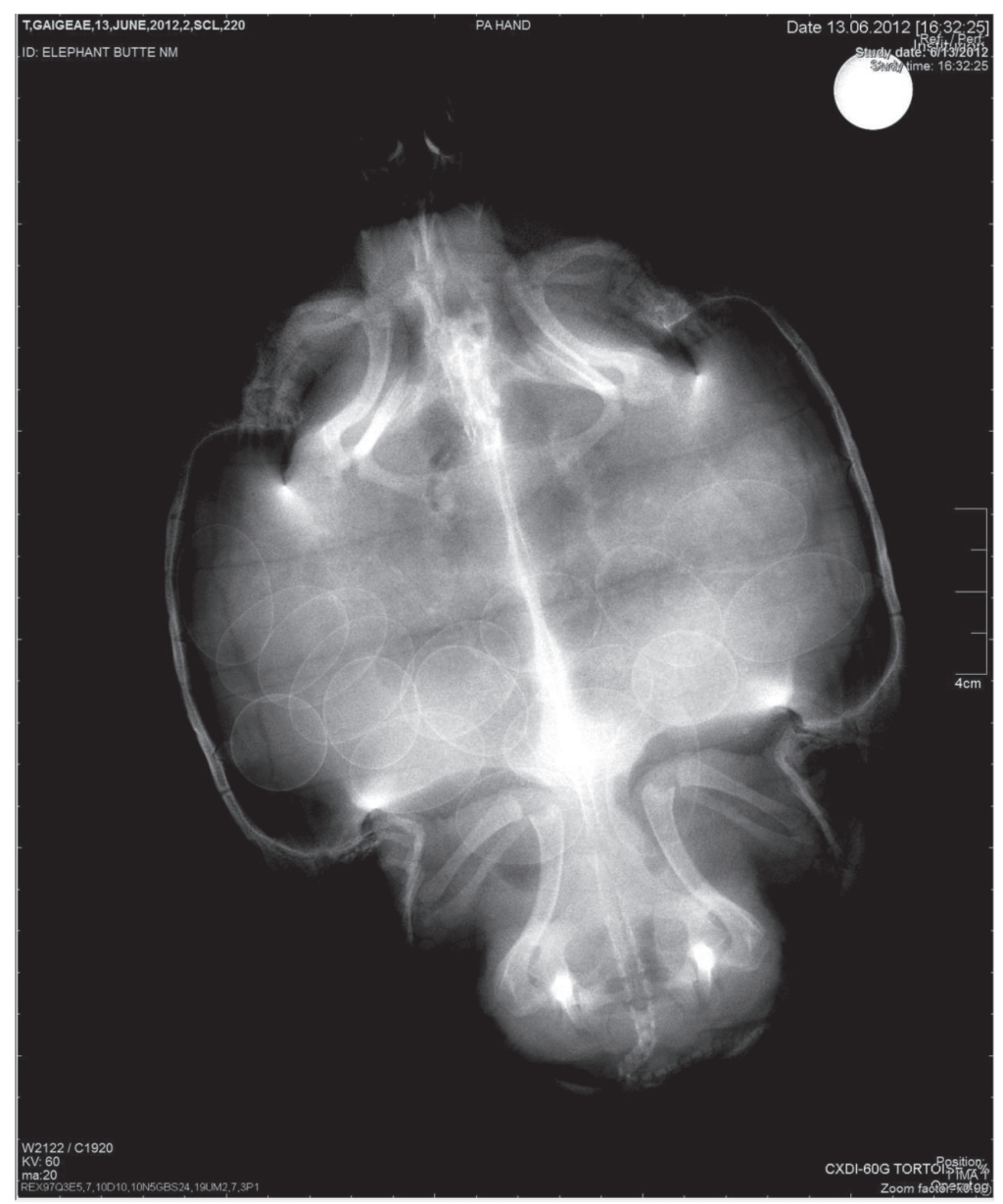

Fig. 1. Female Trachemys g. gaigeae collected in the Rio Grande near the Elephant Butte Reservoir dam in New Mexico. Image was enhanced to make the 18 thinly shelled eggs more visible at the expense of the anterior and posterior margins of the carapace. A penny (19 mm diameter) is shown in the upper right-hand corner for scale.

Seven female T. g. gaigeae ranging from 135 to $245 \mathrm{~mm}$ SLCL were collected in or near EBR, of which $2(29 \%)$ were gravid. One (220 mm SLCL) contained 18 thinly-shelled eggs (Fig. 1) with EW ranging from 22.2 to $24.4 \mathrm{~mm}(\bar{x}=23.2$, SD 0.58). The other $(211$ mm SLCL) contained 12 thinly-shelled eggs with EW ranging from 22.0 to $23.2 \mathrm{~mm}(\bar{x}=$ 22.6, SD 0.4). Mean EW in the larger female was statistically greater than mean EW in the smaller female, and variation in $\mathrm{EW}$ was greater between clutches than within (Student's $t$-test, pooled variance: $t=2.96$, $\mathrm{df}=$ $28, P=0.003)$.

In 2013, all samples came from EBR (Table 1). Eight female Apalone spinifera ranging in size from 201 to $315 \mathrm{~mm}$ SLCL were X-radio- graphed and none had shelled eggs. A single C. picta (166 mm SLCL) had no shelled eggs. Only 2 out of 13 T. g. gaigeae $(15 \%)$ had shelled eggs with the following data: $203 \mathrm{~mm}$ SLCL, 9 eggs with EW ranging from 24.7 to $26.4 \mathrm{~mm}(\bar{x}=25.5$, SD 0.6); and $213 \mathrm{~mm}$ SLCL, 12 eggs with EW ranging from 23.6 to $24.8 \mathrm{~mm}(\bar{x}=24.2$, SD 0.4). This time, mean EW in the smaller female was statistically greater than mean $\mathrm{EW}$ in the larger female, but again, variation in EW was greater between clutches than within (Student's $t$ test, pooled variance: $t=6.062, \mathrm{df}=19.000, P<$ 0.001). The other $11 \mathrm{~T}$. g. gaigeae without eggs ranged from 146 to $245 \mathrm{~mm}$ SLCL. One suspected hybrid, T. g. gaigeae $\times$ T. scripta (209 mm SLCL, with shell and head patterns 


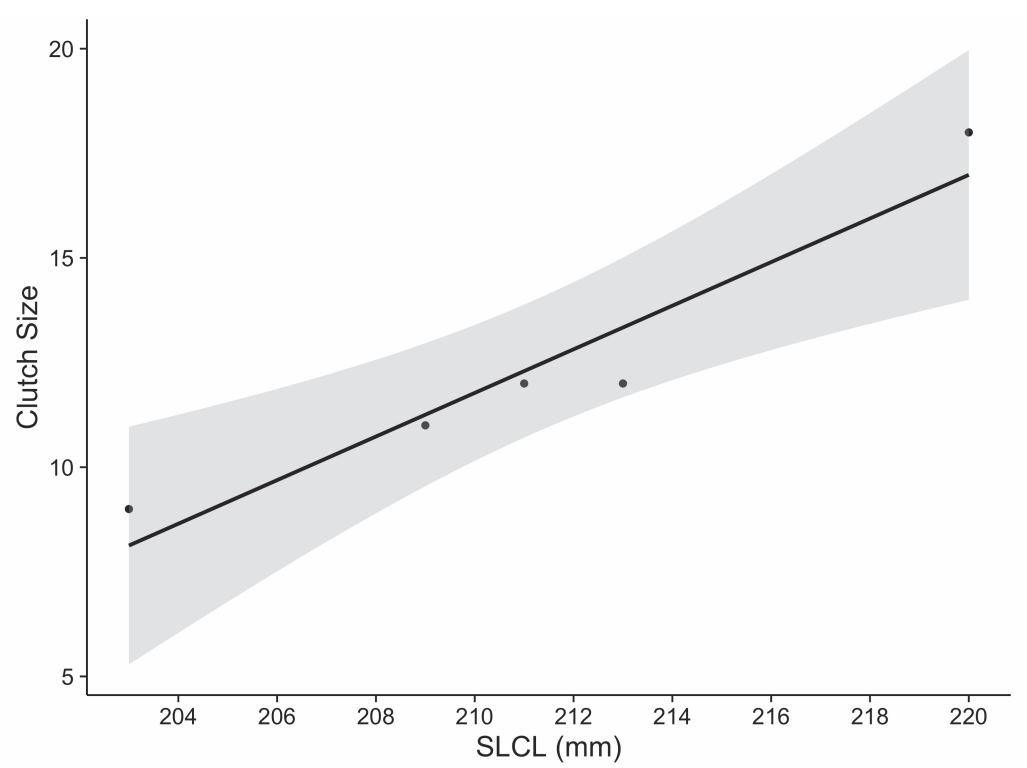

Fig. 2. Clutch size versus straight-line carapace length (SLCL) in Trachemys g. gaigeae, with standard error shown by the shaded region. Data include one suspected hybrid T. g. gaigeae $\times$ T. scripta with a clutch size of 11 eggs.

intermediate between the 2 species), had 11 shelled eggs with EW ranging from 22.6 to $24.9 \mathrm{~mm}(\bar{x}=23.9, \mathrm{SD} 0.8)$. One out of $5 \mathrm{~T}$. scripta females (20\%) had shelled eggs (168 $\mathrm{mm}$ SLCL, 10 eggs) with EW ranging from 20.0 to $22.0 \mathrm{~mm}(\bar{x}=21.3$, SD 0.6$)$. The other 4 female T. scripta ranged from 132 to $225 \mathrm{~mm}$ SLCL.

The proportion of gravid to nongravid female T. g. gaigeae-the species with the largest sample size between years-in 2012 (2 out of 7 ) was not statistically different from the proportion for 2013 (2 out of 13) as shown by Fisher's exact test $(P=0.59)$. Although the sample size is small, clutch size increased with SLCL in the sample of $T$. g. gaigeae, including the suspected hybrid $T$. g. gaigeae $\times$ T. scripta specimen we examined (Fig. 2). The relationship between clutch size and SLCL was significant as shown by linear regression analysis $\left(F_{1,3}=33.33, P=0.01, \mathrm{R}^{2}=0.92\right)$, with clutch size increasing by about 0.52 eggs per millimeter increase of SLCL.

\section{Discussion}

Degenhardt et al. (1996) underscored the need for collecting state-specific data on turtles in New Mexico. They noted that extrapolation of data from eastern populations of tur- tles to those of their congeners or conspecifics in New Mexico may not be appropriate. For example, they noted that Trachemys in New Mexico occur at comparatively high elevations in an otherwise arid landscape and at the westernmost edge of the range for the genus relative to eastern populations of Trachemys. These physiographic differences in habitat may be manifested in variation in reproductive ecology among regions.

Our results provide additional information on the reproductive ecology of female turtles in New Mexico, including only the second record (Table 1) of clutch size for $P$. gorzugi. In addition, our study supplements current knowledge on reproductive ecology for $T$. $g$. gaigeae, C. picta, A. spinifera, and suspected hybrid $T$. g. gaigeae $\times T$. scripta. Furthermore, our records were taken during a long-term drought which has led to decreased surface water levels in EBR and other drainages in New Mexico (Woodhouse et al. 2013, Cook et al. 2015). The effect of drought on the reproductive output of these species is unknown. Others have shown that drought does affect aspects of aquatic turtle ecology (Anthonysamy et al. 2013), including reproductive output (Gibbons et al. 1983). Future research will be required to determine whether longterm drought is exerting changes in turtle 
reproductive ecology in New Mexico. Despite the prudent cautionary note offered by Degenhardt et al. (1996) above, we found little difference between reproductive data for New Mexico C. picta and its conspecifics elsewhere in the United States, except as noted below.

Chrysemys picta is a wide-ranging species in North America, and size at maturity varies depending on subspecies and population. Christiansen and Moll (1973) found that females in New Mexico mature at about $139 \mathrm{~mm}$ carapace length, which is just below the size of our smallest gravid female (144 mm CL). Although numerous studies suggest a positive correlation between body size at sexual maturity and latitude for C. picta (Iverson and Smith 1993, see review in Ernst and Lovich 2009), minimum body size of sexually mature females from New Mexico appears to be well below the upper range of values previously reported for the species in western North America (about 165-177 mm CL; see review in Ernst and Lovich 2009). Clutch size also varies slightly from a mean of 9.9 eggs in New Mexico to 10.5 eggs in Illinois (Morjan 2003).

The range of $P$. gorzugi extends from New Mexico to Tamaulipas, Mexico, and the species is presently at risk from water diversion projects, habitat fragmentation, the pet trade, and limited gene flow (Bailey et al. 2008). Reproductive ecology of $P$. gorzugi is poorly known, and only one other record of clutch size is available in the literature (9 eggs; Degenhardt et al. 1996). The faint outline of eggs in the $\mathrm{X}$-radiograph we observed suggested that the eggs were still being shelled, which means that nesting could have occurred within the month of June or possibly July.

Our data add to available reproductive studies of another comparatively data-deficient species, T. g. gaigeae. The clutch sizes of gravid females at our study area were within the known range of reproductive output in a single clutch (6-29 eggs; Ernst and Lovich 2009). Body size was positively correlated with clutch size in $T$. g. gaigeae. The general pattern of clutch size increasing with body size is well documented and has been suggested in several aquatic turtle species (see review in Ernst and Lovich 2009). However, our study is the first to suggest that relationship in T. g. gaigeae.

In addition, we recorded the presence of eggs in a suspected hybrid of T. g. gaigeae $\times$
T. scripta, further confirming reproductive interactions (see review in Stuart and Ward 2009) between invasive T. scripta and native T. g. gaigeae. Hybridization with T. scripta is considered one of several threats faced by $T$. $g$. gaigeae. Stuart and Ward (2009) note that the presence of breeding populations of T. scripta within the range of $T$. g. gaigeae is "... unconfirmed but appears likely." Our finding of both a gravid female T. scripta and a gravid suspected hybrid supports Stuart and Ward's "likely" conclusion.

Overall, we observed few differences between reproductive parameters for turtles in New Mexico and their conspecifics and congeners elsewhere in the United States. An exception is that females of C. picta may mature at smaller body sizes in New Mexico relative to other western populations elsewhere in the species' vast, primarily eastern North American range.

\section{ACKNOWLEDGMENTS}

This paper is dedicated to our friend and colleague, the late Charlie Painter, with fond memories of his field comradery and outstanding skills at camp cooking, especially his carne adovada. An earlier version of this manuscript benefited from comments provided by Shellie Puffer. Research was partially funded by the U.S. Geological Survey in collaboration with the New Mexico Department of Game and Fish. Any use of trade, product, or firm names is for descriptive purposes only and does not imply endorsement by the U.S. government.

\section{Literature Cited}

Anthonysamy, W.J.B., M.J. Dreslik, and C.A. Phillips. 2013. Disruptive influences of drought on the activity of a freshwater turtle. American Midland Naturalist 169:322-335.

Bailey, L.A., J.R. Dixon, R. Hudson, and M.R.J. Forstner. 2008. Minimal genetic structure in the Rio Grande cooter (Pseudemys gorzugi). Southwestern Naturalist 53:406-411.

Buhlmann, K.A., T.S.B. Akre, J.B. Iverson, D. Karapatakis, R.A. Mittermeier, A. Georges, A.G.J. Rhodin, P.P. VAN DiJK, AND J.W. GiBBons. 2009. A global analysis of tortoise and freshwater turtle distributions with identification of priority conservation areas. Chelonian Conservation and Biology 8:116-149.

Christiansen, J.L., And A.E. Dunham. 1972. Reproduction of the yellow mud turtle (Kinosternon flavescens flavescens) in New Mexico. Herpetologica 28:130-137.

Christiansen, J.L., And E.O. Moll. 1973. Latitudinal reproductive variation within a single subspecies of 
painted turtle, Chrysemys picta belli. Herpetologica 29:152-163.

Cook, B.I., T.R. Ault, and J.E. Smerdon. 2015. Unprecedented 21st century drought risk in the American Southwest and Central Plains. Science Advances 1(1):e1400082.

Degenhardt, W.G., and J.L. Christiansen. 1974. Distribution and habitats of turtles in New Mexico. Southwestern Naturalist 19:21-46.

Degenhardt, W.G., C.W. Painter, and A.H. Price. 1996. Amphibians and reptiles of New Mexico. University of New Mexico Press, Albuquerque, NM.

Ernst, C.H. 1992. Trachemys gaigeae. Catalog of American Amphibians and Reptiles 538:1-4.

Ernst, C.H., AND J.E. LOVICH. 2009. Turtles of the United States and Canada. 2nd edition. Johns Hopkins University Press, Baltimore, MD.

GibBons, J.W. 1988. Turtle population studies. Carolina Tips 51:45-47.

Gibbons, J.W., J.L. Greene, and J.D. Congdon. 1983. Drought-related responses of aquatic turtle populations. Journal of Herpetology 17:242-246.

Hinton, T.G., P.D. Fledderman, J.E. Lovich, J.D. CongDON, AND J.W. GibBONS. 1997. Radiographic determination of fecundity: is the technique safe for developing turtle embryos? Chelonian Conservation and Biology 2:409-414

Iverson, J.B., AND G.R. Smith. 1993. Reproductive ecology of the painted turtle (Chrysemys picta) in the Nebraska Sandhills and across its range. Copeia 1993:1-21.

LEGLER, J.M. 1960. Remarks on the natural history of the Big Bend slider, Pseudemys scripta gaigeae Hartweg. Herpetologica 16:139-140.

Legler, J., AND R.C. VogT. 2013. The turtles of Mexico: land and freshwater forms. University of California Press, Berkeley, CA. 416 pp.

Lovich, J.E. 2016. Turtle reproductive ecology data, New Mexico, 2012-2013: U.S. Geological Survey data release $10.5066 / \mathrm{F} 7 \mathrm{~N} 014 \mathrm{~N} 2$

Lovich, J.E., and K.R. BEaman. 2008. Distribution of native turtles in the arid southwestern United States with comments on Kinosternon sonoriense: a species presumed to be lost from California's herpetofauna. Pages 127-134 in R.E. Reynolds, editor, The 2008 Desert Symposium Field Guide and Proceedings. Desert Studies Consortium, California State University, Fullerton, CA.

LOVICH, J.E., AND J.R. ENNEN. 2013. A quantitative analysis of the state of knowledge of turtles of the United States and Canada. Amphibia-Reptilia 34:11-23.

Lovich, J.E., C.T. LaRue, C.A. Drost, and T.R. ArunDEL. 2014. Traditional cultural use as a tool for inferring biogeography and provenance: a case study involving painted turtles (Chrysemys picta) and Hopi Native American culture in Arizona, USA. Copeia 2014:215-220.

Miller, K., G.F. Birchard, M.J. Packard, and G.C. PACKARD. 1989. Trionyx spiniferus (spiny softshell turtle). Fecundity. Herpetological Review 20:56.

Morjan, C.L. 2003. Variation in nesting patterns affecting nest temperatures in two populations of painted turtles (Chrysemys picta) with temperature-dependent sex determination. Behavioral Ecology and Sociobiology 53:254-261.

Morjan, C.L., AND J.N. Stuart. 2001. Nesting record of a Big Bend slider turtle (Trachemys gaigeae) in New Mexico, and overwintering of hatchlings in the nest. Southwestern Naturalist 46:230-234.

R CORE TEAm. 2013. R: a language and environment for statistical computing. R Foundation for Statistical Computing, Vienna, Austria. ISBN 3-900051-07-0. http://www.R-project.org

StUART, J.N. 1995. Notes on aquatic turtles of the Rio Grande drainage, New Mexico. Bulletin of the Maryland Herpetological Society 31:147-157.

Stuart, J.N., And C.H. ERnst. 2004. Trachemys gaigeae (Hartweg) Mexican Plateau slider. Catalogue of American Amphibians and Reptiles 787:1-6.

Stuart, J.N., and C.W. Painter. 1997. Trachemys gaigeae (Big Bend slider). Reproduction. Herpetological Review 28:149-150.

Stuart, J.N., and C.W. Painter. 2002. Observations on the diet of Trachemys gaigeae (Testudines: Emydidae). Bulletin of the Maryland Herpetological Society $38: 15-22$

Stuart, J.N., And C.W. Painter. 2006. Trachemys gaigeae (Big Bend slider). Reproductive characteristics. Herpetological Review 37:79.

StUART, J.N., AND J.P. WARD. 2009. Trachemys gaigeae (Hartweg 1939)—Big Bend slider, Mexican Plateau slider, Jicotea de la Meseta Mexicana. Pages 032.031-032.012 in A.G.J. Rhodin, P.C.H. Pritchard, P.P. van Dijk, R.A. Saumure, K.A. Buhlmann, J.B. Iverson, and R.A.E. Mittermeier, editors, Conservation biology of freshwater turtles and tortoises: a compilation project of the IUCN/SSC Tortoise and Freshwater Turtle Specialist Group. Chelonian Research Monographs 5.

WebB, D. 1985. What are the criteria for presuming native status? Watsonia 15.

Woodhouse, C.A., D.M. Meko, D. Griffin, and C.L. CASTRo. 2013. Tree rings and multiseason drought variability in the lower Rio Grande Basin, USA. Water Resources Research 49:844-850.

Received 25 January 2016 Accepted 23 May 2016 